\title{
Lessons Learned from the Lorestan Flood Crisis: Relief Experience in Pol-e-Dokhtar Flood
}

\author{
Hamidi Farahani. ${ }^{1}$, Niknam Sarabi. H², *Farsi. $Z^{3}$
}

We would like to share the experiences of a healthcare provider (second author) who attended in Pol-e-Dokhtar to help the flood-hit people from 01 to 04 April and 09 to April 12.

Since mid-March to April 2019, widespread flash flooding affected at least 23 provinces of Iran's 31 provinces (1), with unprecedented rainfalls in the most regions of the country that had endured decades-long drought. The floods were mainly caused by the overflow of rivers because they had not been properly dredged in time and that some construction had been built near the riverbeds. At least 77 people have died and 1076 others have been injured in massive flooding in Iran in recent months (2). The recent floods in Iran are estimated to have caused up to $\$ 2.5$ billion in damages so far (3).

The first flash flood occurred in the northeast of Iran on March 19 and the second one struck the west and southwest on March 25 (1). Till 4 April, The Lorestan Province flood was the third flash flood to hit Iran in the last months with 15 death toll (4) and 256 injured people (5). The water has risen by as much as 2.5-3 meters in Lorestan (6). Pol-e-Dokhtar and Mamulan experienced some of the heaviest rains and flooding in Lorestan and were engulfed by flood. The water level in Pol-e-Dokhtar and Mamulan had reached to rooftops of houses. Widespread flash flooding and landslides cut off many roads, interrupting both traffic and telecommunications, and loss of clean water supply. The main railway line linking Tehran to the south of Iran had also blocked by the flood. The airport in Khorramabad was flooded and the Lorestan main air link to the rest of
Iran was cut. Bridges collapsed and oil and gas pipelines destroyed and the residential homes, public building, and infrastructure were damaged. Helicopters could not take off due to the bad weather in the first-night disaster. A mass of mud had filled homes, villages, and cities such as, Delfan, Mamulan, and Doreh-Chegeni. The level of mud in parts of Pol-e-Dokhtar was between 1.5-3 meters high (7). According to preliminary estimates, the amount of damage in Poldokhtar County in different parts was about 2 billion tomans (8).

Some people had taken refuge in the surrounding mountains. This flash flood left thousands homeless. Flood-hit people did not access to drinking water, food, heating equipment, and toilet. The risk of infectious diseases was high due to the loss of clean water supply. Schools were destroyed and parents were worried about their children. Some experts warned that if no immediate measure was adopted, the Pol-e-Dokhtar could have faced a humanitarian crisis.

The professional and voluntary relief teams including Iran's Armed Forces (IAF), Iran's Red Crescent (IRC) rescue workers, Municipal Forces, voluntary relief teams, and other organization started rescue and relief operations. They should start immediate measures, including transporting people to a safe area. However, the severe flooding and landslides throughout the region disrupted the rescue and relief teams' road access to people. Disruption of cellular phone networks and internet connections also impaired disaster management. According to one of the authorities, there was mismanagement in rescue and aid operations and people

Hamidi Farahani R, Niknam Sarabi H, Farsi Z. Lessons Learned from the Lorestan Flood Crisis: Relief Experience in Pol-e-Dokhtar Flood. Military Caring Sciences. 2019; 6 (3). 169-173.

Submission: 12/12/2019 Accepted: 31/12/2019 Published: 21/12/2019

1- Specialist in Infectious and Tropical Diseases, Assistant Professor, Infectious Diseases Department, Faculty of Medicine, Aja University of Medical Sciences, Tehran. Iran.

2- MSc Student in Critical Care Nursing, Student Research Committee, Faculty of Nursing, Aja University of Medical Sciences, Tehran, Iran.

3- ( ${ }^{*}$ Corresponding Author) Ph.D. in Nursing, Associate Professor, Research and Community Health Department, Faculty of Nursing, Aja University of Medical Sciences, Tehran, Iran. Email: z.farsi@ajaums.ac.ir; zahrafarsi@gmail.com 
were in a rebellious mood in the first days after the disaster (9). For instance, the distribution of necessary supplies to the people was inappropriate. Sometimes these supplies were not available to flood-hit people who were busy with cleaning the houses and streets. On the contrary, others who had not been affected received the supplies. In the following days, the distribution of essential items became more coherent and more organized. In the early days, there was no single leadership between relief agencies, which led to inadequate coordination and sometimes disagreement. After a few days, the Chief Staff of the Iranian Armed Forces as a commander authorized to use forces to provide "full and organized" assistance in flood-stricken areas in a coordinated manner.

IAF, IRC, and other organizations have used their equipment to help people. At least 150,000 people had been asked to immediately evacuate as water had started to close streets and engulf buildings in some regions of Lorestan (10). The area at risk of flooding had been evacuated. Helicopters had been dispatched by the Army to the inundated areas in Pol-e-Dokhtar. The helicopters were equipped with night-vision equipment and facilitated rescue operations to people stranded on the rooftops of their houses, and provided food and drinking water for flood-hit people, and transferred necessary equipment for relief workers. The Army moved tactical military bridges, armored personnel carriers, terrain rescue vehicles, boats, crane trucks, patrol, and reconnaissance and cargo plane to flood-stricken areas where road vehicles cannot be used. By the efforts of the IAF and other organization, the land connection was provided for relief and rescue teams. The volunteer forces (including the researcher), IAF, and other organizations also accompanied people to resolve the problems and adopted effective measures to reconstruct and clean the towns from thick layers of mud. IRC and other organizations also supported Lorestan by rendering relief services, providing emergency shelters, water pumps, electric generators, basic health care units, blankets, tents, food, mineral water, etc.

The field hospital of the Army set up in Pol-e-Dokhtar. The field hospital was equipped with an emergency unit, operations room, and experienced healthcare providers including expert physicians and nurses. Also, the emergency operations team was sent to the province. Relief workers and rapid response forces were serving the affected people. They were working to prevent contagious diseases. Rescue, medical and care operations including patient visits, medication, wound dressing, vaccination including tetanus vaccine injection were among those performed by the medical team (including the researcher). After the relief and rescue operation, the reconstruction began immediately and continues so far.

We tried to demonstrate the characteristics of the Lorestan flood disaster. Volunteer and professional relief and rescue teams could prevent a humanitarian crisis in Lorestan and minimize casualties and injuries. However, the experiences of the researcher show that one of the challenges in the disaster regions was management challenges due to the extent of the crisis, not acting quickly enough, and inadequate coordination of responses in the first days after the flood. It seems that the problems modified with organized management and concentration on priorities in the days after the disaster. The recent flood in Lorestan has left some casualties and injuries and has incurred serious damages to a large part of Lorestan. In the next step, the organizations should focus on reconstruction projects and rehousing operations and continue their efforts until life in affected areas would be restored to normal. As well as, longterm continuous effort is necessary for a full recovery of people. It seems there is an urgent need to incorporate psychological rehabilitation of the flood-affected. We believe that learned lessons from this disaster could contribute to minimizing the death toll and damages in future disasters. Compliance with unified command, organized management, accelerated assistance, correct Management of volunteers in the area, correct management of resources and facilities distributed among victims, and documenting services provided to prevent abuse of some beneficiaries, psychological support along with prevention and treatment of physical injuries to victims, is the most important lessons learned in this experience, which is suggested to be addressed by the authorities in the similar crisis.

\section{Conflict of interest}

The authors declare that there is no conflict of interest.

\section{Acknowledgment}

None. 


\title{
درس آموختههاى بحران سيل لرستان: تجربه امدادر سانى در سيل يلدختر
}

\author{
رامين حميدى فراهانى'، حجت نيكنام سرابى"، "زهرا فارسى"
}

ايران قطع شد. يلها، خطوط نفت و كاز، منازل مسكونى مردم، ساختمانهاى عمومى و زيرساختها تخريب شدند. در شب اول بحران، هلى كويترها به دليل نامساعد بودن شرايط جوى قادر

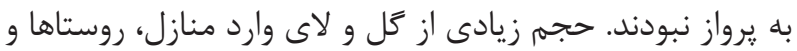
شهرهايى همجون دلفان، معمولان و دوره - خَّينى شد. ارتفاع

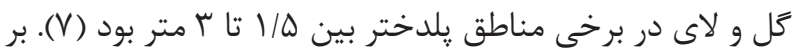

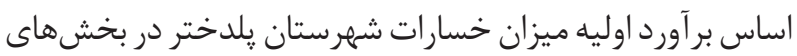

مختلف حدود · له ميليارد تومان بود (N). برخى از مردم منطقه به كوههاى اطراف يناه بردند. اين سيل هزاران بع خانمان بر جاى كذاشت. مردم سيلزده به آب آشاميدنى، غذا، تجهيزات گرمايى و سرويس بهداشتى دسترسى نداشتند. خطر بروز بيمارىهاى عفونى به دليل فقدان آب آشاميدنى بالا بود.

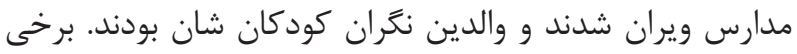
كارشناسان هشدار دادند كه اخر اقدامات سريع انجام نشود، يلدختر با يك فاجعه انسانى روبرو مىشود. تيمهاى امدادرسانى حرفهاى و داوطلب شامل كاركنان نيروهاى مسلح جمهورى اسلامى ايران (ج. I. I.)، كاركنان امدارسانى هلال احمر ايران، نيروهاى شهردارى، تيمهاى امدادرسان داوطلب و ساير سازمانها عمليات امداد و نجات را شروع نمودند. آنها

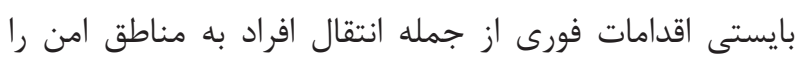

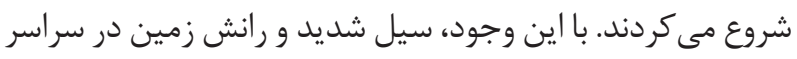

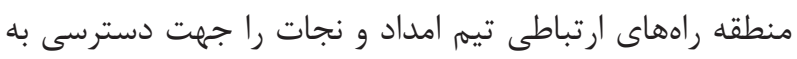

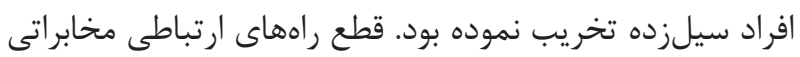

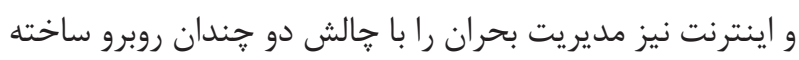
بود. طبق اظهارات يكى از مسئولين، مديريت مناسبى در عمليات
هدف از اين مقاله به اشتراك گذاشتن تجارب يكى از كاركنان بهداشت و درمان (نويسنده دوم) است كه جهت امدادرسانى داوطلبانه به مردم سيلزده يُلدختر از تاريخ rا تا ها فروردين و

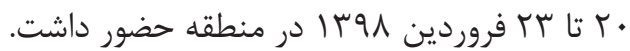
از اواخر اسفند 1هץ| بارشهاى بـسابقه در اكثر مناطق كشور كه دهdها خشكسالى را يشت سر كذرانده بود، منجر به بروز سيل

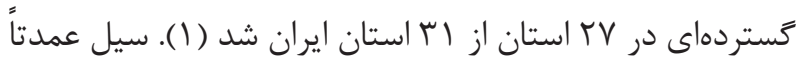
در نتيجه طغيان رودخانههايى كه به درستى و در موعد مقرر لايه

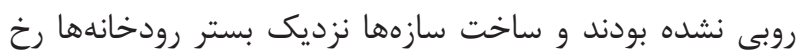

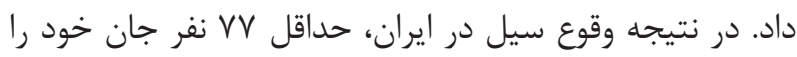

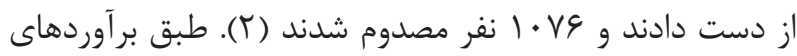
انجام شده سيلهاى اخير بالغ بر دو نيم ميليارد دلار به ايران

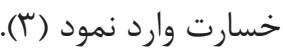

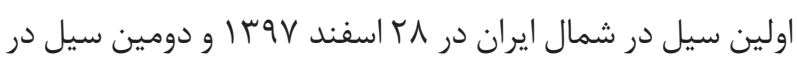
غرب و جنوب غرب ايران در ه فروردين لهوسا به وقوع ييوست

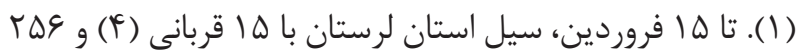

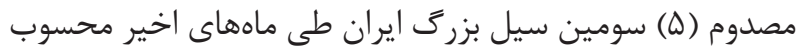

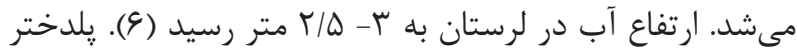
و معمولان بيشترين ميزان بارندگى و سيل را در استان لرستان

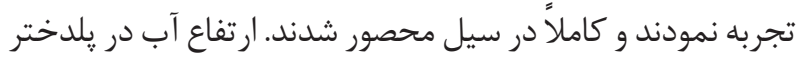
و معمولان به يشت بام خانهها رسيد. سيل گسترده و رانش زمين منجر به تخريب راههاى ارتباط زمينى، قطع تردد و ارتباطات مخابراتى و قطع آب منطقه شد. خط راه آهن اصلى نيز كه تهران

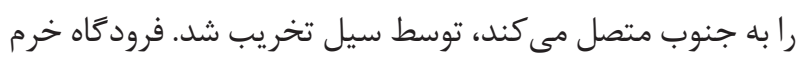

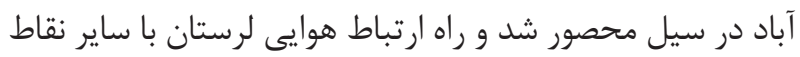


آب معدنى و ساير موارد ضرورى از مردم سيلزده حمايت نمودند.

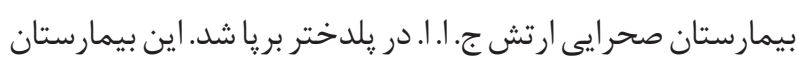
صحرايى مجهز به واحد اورزانس، اتاق عمل و كاركنان با تجربه

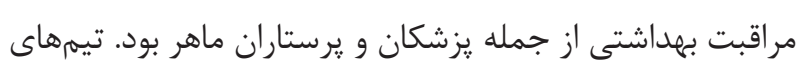

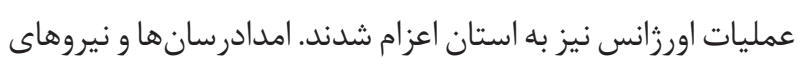
واكنش سريع در حال كمك به مردم سيلزده بودند. آنها در حال

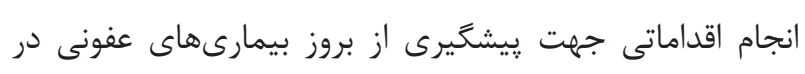

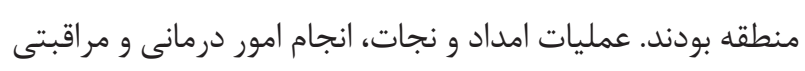

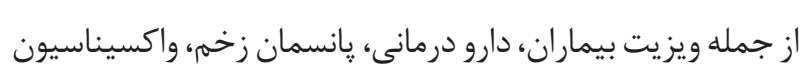

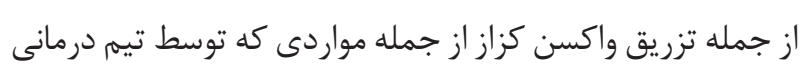

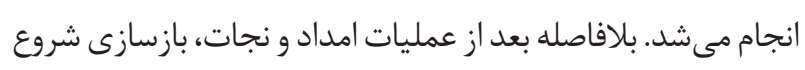
شد و تا كنون ادامه دارد.

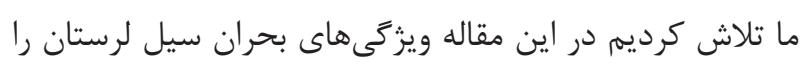
نشان دهيه. تيمهاى حرفهاى و داوطلب امداد و نجات توانستند از بروز يك فاجعه انسانى در لرستان بيشگيرى نمايند و آمار تلفات

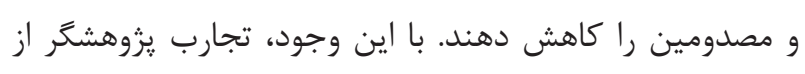
حضور در منطقه اين بود كه يكى از جالشها در مناطق بحران

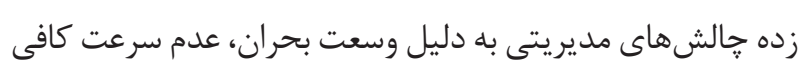

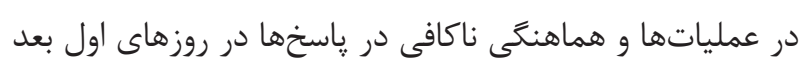

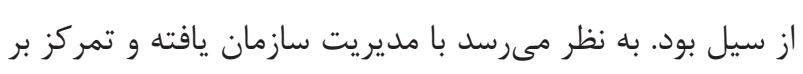

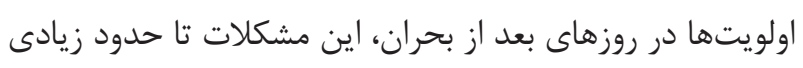
تعديل شد. سيل اخير لرستان تعدادى قربانى و مصدوم به جاى كذاشت و آسيبهاى زيادى را به مناطق وسيعى از استان وارد نمود.

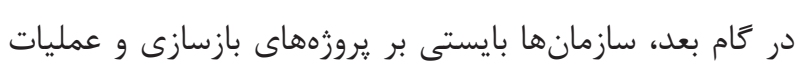

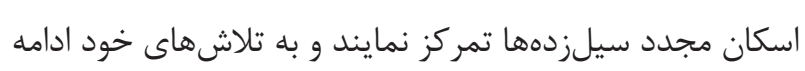

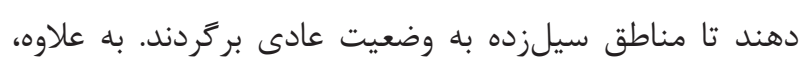

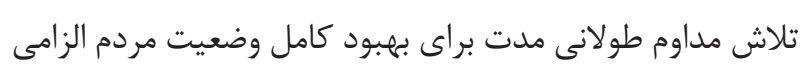

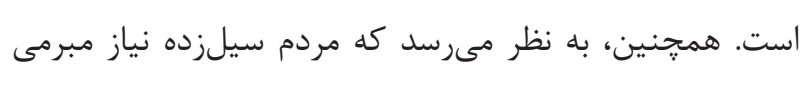

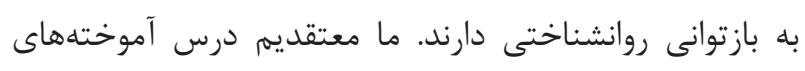

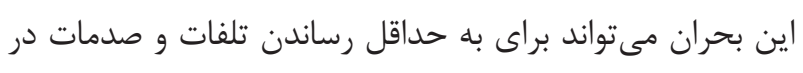

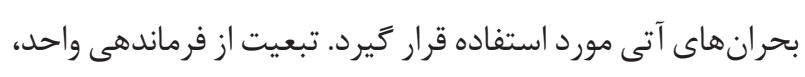
مديريت سازماندهى شده، تسريع در امر امدادرسانى، مديريت

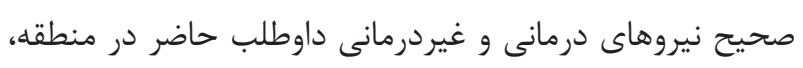

امداد و نجات وجود نداشت و اين امر منجر به خشمكين شدن

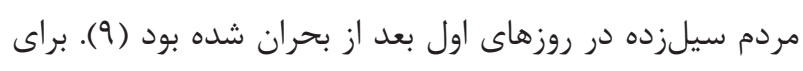

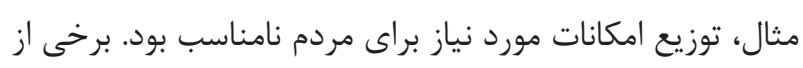

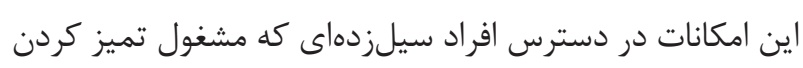

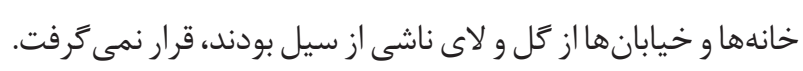

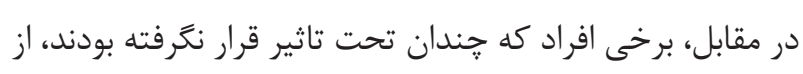

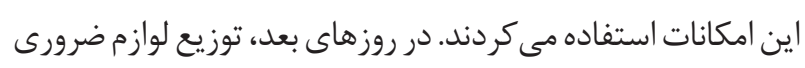

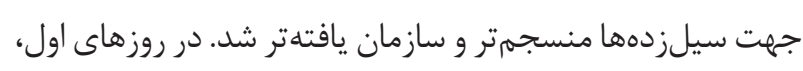
يكى رهبرى واحد بين آزانسهاى امدادرسان وجود نداشت كه اين

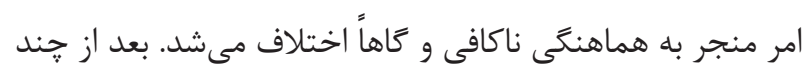

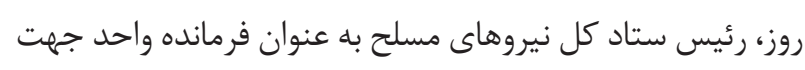

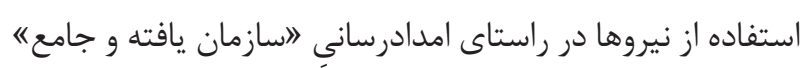
به مناطق سيلزده به روشى هماهنَ انتخاب شد.

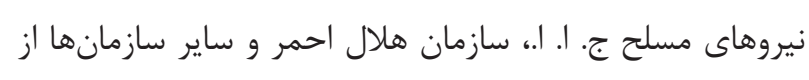
كل تجهيزات خود جهت كمك به مردم استفاده نمودند. به دليل نزديك شدن سيل به خيابانها و ساختمانها در برخى مناطق لرستان، حداقل از • لها هزار نفر خواسته شد كه منطقه را سريعاً

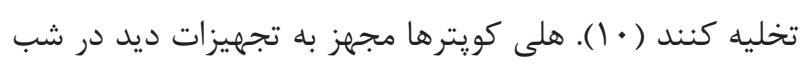

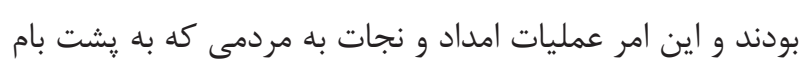

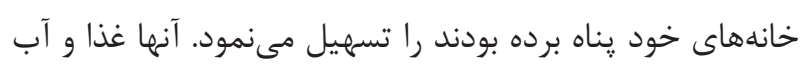

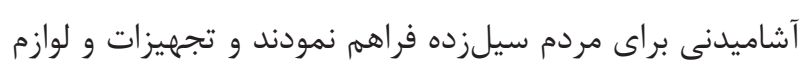

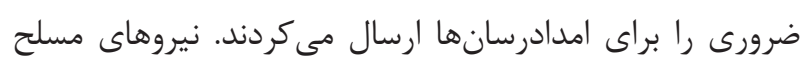

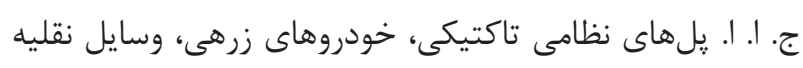

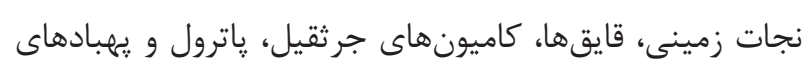

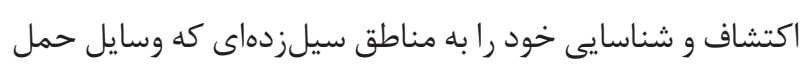

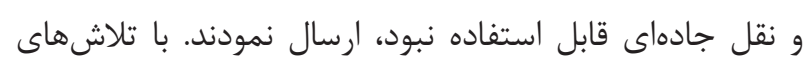

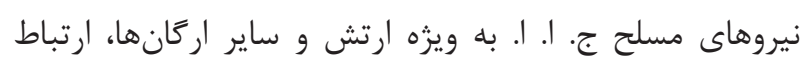

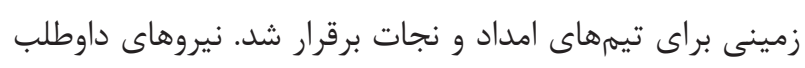

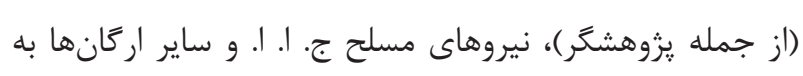
كمك مردم براى حل مشكلات شان شتافتند و اقدامات موثرى جنى

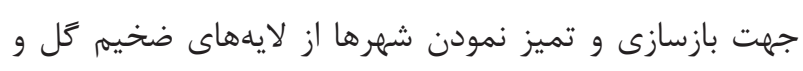

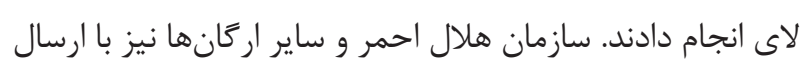

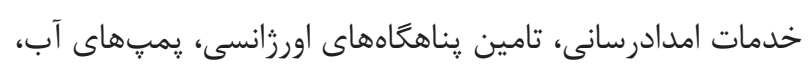

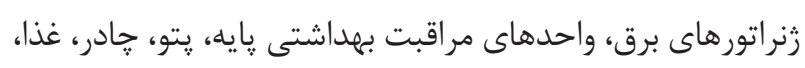




$$
\text { بحرانهاى احتمالى آتى مورد توجه مسئولين قرار گيرد. }
$$

تضاد منافع

در اين مقاله هيج گونه تضاد منافعى وجود ندارد.
مديريت صحيح منابع و امكانات توزيع شده بين قربانيان و ثبت و مستند نمودن خدمات ارائه شده جهت پيشخيرى از سوء استفاده عدهاى سودجو، حمايتهاى روحى روانى در كنار بيشغيرى و درمان آسيبهاى جسمانى وارده به قربانيان از جمله مهمترين

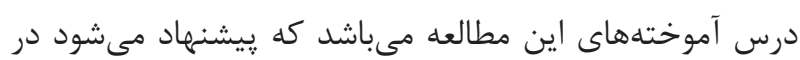

\section{References}

1- Iran Front Page. Aid operations start in Iranian cities most affected by flood. Available from: https://ifpnews.com/exclusive/aidoperations-start-in-irans-areas-most-affected-by-flood/. April 02, 2019.

2- Latest News. Flood casualties reached 77 people. Available from: http://akharinkhabar.ir/social/5157515. April 09, 2019. (Persian)

3- Eghtesad Online. Iran floods' damage estimated at $\$ 2.5 \mathrm{~b}$. Available from: https://www.en.eghtesadonline.com/Section-economy4/28546-iran-floods-damages-estimated-at. April 15, 2019.

4- Iranian Legal Medicine Organization. Flood victims reached 70. Available from: http://mo.ir/index.php?module $=c d k \&$ fun $\mathrm{c}=$ loadmodule \&system $=\mathrm{cdk} \&$ sismodule $=$ user/content_view. php\&sisOp=view\&ctp_id=691\&cnt_id=89322\&id=4482. April 06, 2019. (Persian)

5- Emergency Information Center of the Country. General statistics of casualties and deaths atmospheric events. Available from: http:// www.emsnews.ir/24205/. April 09, 2019. (Persian)

6- Times Live. Iran orders evacuation of flood-hit western cities.

Available from: https://www.timeslive.co.za/news/world/201904-02-iran-orders-evacuation-of-flood-hit-western-cities/. April 02, 2019.

7- Persia Digest. Pol-e Dokhtar and Mamulan drowned in mud (photos). Available from: https://persiadigest.com/Pol-e-Dokhtarand-Mamulan-drowned-in-mud. April 15, 2019.

8- Islamic Republic of Iran Ministry of Health and Medical Education. Poldokhtar's People expect to build coastal walls in riverside villages. Available from: http://behdasht.gov.ir/?siteid=1 \&pageid=1508\&newsview=188474. Dec 30, 2019. (Persian)

9- Iran Daily. Revolutionary Guards — "People are in rebellious mood" amid floods. Available from: https://eaworldview. com/2019/04/iran-daily-revolutionary-guards-people-are-inrebellious-mood-amid-floods/. Apr 03, 2019.

10- Press TV. Iran Floods: New alerts issued as heavy rains continue. Available from: https://www.presstv.com/ DetailFr/2019/04/01/592337/Iran-floods-rainfall-Tehranemergency. April 01, 2019. 